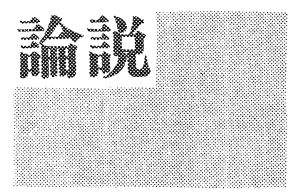

応用磁気の発展に想う

\title{
On the Prosperity of Applied Magnetics
}

\author{
川西健次旦本大学理工学部 \\ Kenji Kawanishi College of Science \& Technology, Nihon University
}

私が磁気に係わりをもつようになったのは昭和35年頃 であろうか, ちょうど磁気増幅器の研究が各所で始まっ た頃であった．沢山の文献が出ていて，随分読んだもの であったが，文献だけでは面白くない，ひとつ作ってみ ようといら事になってハ夕と困ったのは鉄心材料であっ た. 外国の文献にはドイツの Permenom-5000 Z が盛ん に書かれているけれども手元にはなかった．止むなく硅 素鋼板（熱間板）で 3 脚鉄心を作ってやってみたが，少 しも増幅をしない，今度はパーマロイで作ってみて，や っと少し増幅をした．この頃になると東北金属のセンデ ルタが手に入るようになって，研究の成果も出るように なってきた．今から思えば 3 脚鉄心は笑い話であるが， 経験が必要である事をつくづくと知らされた 1st step で あった. 数年後, 大阪大学の桜井良文教授の研究室にお 伺いした折, やはり熱間板で試みられた磁気増幅器が戸 棚に展示されているのを見て，お互いに笑ったものであ る.

ようやく研究も軌道に乗り, 私は磁気増幅器の跳躍現 象で幾つかの論文を書いている頃, アメリカの $\mathrm{GE}$ 社か ら SCR (サイリスタの商品名) のニュースが伝わった. 当時は電気学会に磁気増幅器調查専門委員会があったの であるが，このニュースは直ちにその委員会にも伝えら れて, 早速に SCR と磁気増幅器とどちらが生き残るで あろらかと熱心な討議が行なわれた。 その席の空気では どうも磁気増幅器は生き残れないかも知れないとの不安 を抱いている人が何人かは居たように思われた。 それか ら10年くらい経ってから東北金属の若生敏生さんに聞い たら，七ンデルタの売れ行きは伸びているとの事で胸を なでおろした次第である。どうも磁気を応用する立場か らすると絶えず半導体の事が気になるすので，記憶素子 然り, 直流増幅器然り等々である. 当たっているかどう かはわからないが，絶えず半導体を意識しながらよりよ い応用をと諸先輩のされた努力が応用磁気の今日の隆盛 をもたらしたのであろう。

1963年になって IEEE の MAGグループによって第 1 回 Intermag. が米国の Washington D.C. で開かれた. ちょうど私は大学から海外出張を命じられていたので, この会議に出席することができたのは幸運でのった。
学会のセッションでは, 磁気増幅器および変調器, 磁 気と半導体の組合せ回路などが華やかな話題で, 更に, 東京大学の高橋, 後藤両教授の発明になるパラメトロン 一一特に薄膜パラメトロン, ガラス基板に円形に蒸着し たパーマロイ薄膜の記憶への応用やクリープ現象の論文 が多く, 垂直磁化膜, 磁気バブル, 非晶質磁性材料など は全く話題にのぼってはいなかった，この出張中は大阪 大学の桜井教授と一緒で, 米国および欧州の研究を見て 歩いた. 励振周波数 $40 \mathrm{MHz}$ の薄膜パラメトロンやクリ ープ現象の研究, ツイスタ, フェライト板の記憶などが 盛んに研究されていた頃で, また, バローズでは $\mathrm{Pb}$ と Sn を用いた 超電導論理素子の研究を盛んに行なってい て, 超電導形電子計算機の実現近しの感を深めていたの であるが，今日まで実現していないのは残念である。こ の見学旅行の結果, 桜井教授は, 磁気増幅器は研究とし てはする事もあまりなくなっていたので, 磁性薄膜の研 究を決心されたらしい. 今日の広島大学の楠田哲三教授 の $\mathrm{MnBi}$ の研究や九州大学の小西進助教授の Wall dynamics の研究はこの成果でありましょう.

毎年の Intermag. や3M会議には，わが国から多数の 論文が発表された. 1965，6年頃であろらか. 当時, 電気 学会の磁気応用調査専門委員会の委員長をされていた早 稲田大学の大照完教授は当時の磁気応用分野の研究に物 理学者の協力が必要であることを痛感され，東京大学物 性研究所の近角聡信教授に同委員会の委員になっていた だいて，ここに始めて応用磁気の分野において理学と工 学の協力態勢がスタートしたのである. その頃, 日本の 学者の Intermag. における貢献のせいで, Yale 大学の Barker 教授から日本で Intermag. を開催しないかとの 話があり，同委員会が中心になって開催の準備をするこ とになった. Intermag. が広い分野にわたっているので 一学会だけの主催では無理といら意見で, 日本学術振興 会の中に応用磁気第137委員会が設立され, 隔月 1 回の 砢究会でシンぷジュームや Intermay. の報告が行なわ れると共に 1972 年京都での Intermag. の準備をするこ とになった. 委員長は当時 KDD 研究所長であった大島 信太郎博士であった. Spain が J.A.P. 誌上に DTPL (domain tip propagation logic) を発表したのが 1966 年 
の事であるから，当時の computer magnetics の情況が 伺えよう.

パーマロイなどの薄膜の水平磁化膜で磁区に情報を担 わせて，これの転送を自由に制御したいというのが当時 の目標であったと思われる. Bobeckがオーソフェライト で垂直磁化膜の磁区, すなわち磁気バブル，を発表した のが1967年で, それまでは水平磁化膜のものであった. この磁気バルブは世界中の関心を集めることになった. そのうちに 1970 年になって同じベル研究所の Boyle \& Smith によって CCD (charge coupled device) が発表さ れて, 磁気グループは磁気バブルも半導体によってとっ て代わられるのではないかとの不安におののかされた.

数回にわたって転送速度, ビット密度, 不揮発性につい て半導体グループと討議を重ね, 磁気グループは磁気バ ブルは完全に不揮発性であることが最も優れた特長であ ると自負していたようである。 今日，両方ともそれぞれ 実用化されているのは真に御同慶の至りである.

1972年京都で行なわれた'72 Intermag. では, 磁気バ ブル関係 34 件, 薄膜メモリー 11 件, core devices 9 件, domain tip 3 件, 光磁気記録17件, 記憶, 記録およびシ ステム64件, その他で, 時代の趨勢が伺える. この学会 の前からベル研究所ではハードバブルがある事を知って いたので, 会議の席では複雑な心境であったのではない かと思われる.

?72 Intermag, の終る頃, 関係者の間では応用磁気137 委員会は今後存続することが可能だろうか, 各分野はど れほど発展するだろらか，といらことについて完全な見 通しがあったわけではなかったように思う。 せっかく作 った工学系と理学系の共同の場としてお互いに恩恵を受 けている 137 委員会を学会として残そうと決まるまでに は大分長い時間がかかった.

話は前後するが1971年頃, 大阪大学の桜井教授, 早稲 田大学の小林寛教授および私の三人が相談して，ひとつ われわれも磁気バン゙ルの忉料を作らうではないかという ことになって，桜井教授は CVD 法で，私は LPE 法で ガーネット膜を作ろらといらことになった．小林教授は その少し前からフラックス法でオーソフェライトを作っ ていた. $30 \mathrm{cc}$ 程度の白金坩融では大きいオーソフェラ イトは成長しなくて，小林教授からいただいたのは，初 めてできたマッチの軸ほどの太さで長さ $3 \mathrm{~mm}$ くらいの ものであった．確かに垂直磁化になっているようである が，方位を決めて切断，研磨することはとてもできなか
った. 当時は東北金属, 日本電気などではオーソフェラ イトが作られ，また電々公社武蔵野通研，日本電気，富 土通でガーネット膜は作られていたが，作り方について は教えてもららわけにもいかず，独自で作るはめになっ

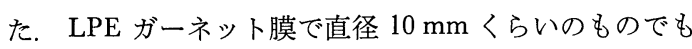
100 万円以上寸ると云われていたので，試料をわけても らうわけにもいかず，自力で作ろらとしたのである．研 磨したGGG 基板もなかなか入手できず，止むなく $400 x$ ッシュくらいに磨いたものを入手してサイトンで磨いた が，エッチングするとエッチピットばかりで物にならな かった，暫くして研磨した GGG が容易に入手できるよ うになったので, もう研磨するのは止めにしたが, 研磨 も素人から始めると難しいものだなあとつくづく知らさ れた.

LPE を始めるようになったのは, 応用磁気第 137委員 会での Intermag. 報告会で, LPE 法だと GGG を白金 線で吊って15分くらい浸すだけでできる, といら見て来 られた方のお話があったからである. 炉も学生と一緒に なって 3 ケ月くらいかかって作った. 今までデータがな いし, 発表されたデータもほとんどない状態だったの で, 飽和温度を決めるにも苦労した. 或る時は GGGを 一分くらいつけただけで上げて見ると GGG がなかっ た．融けたのである．またメルトの組成もデータのない ままに始めたのでパラメータの決定に困った. メルト組 成を決める $R_{1}$ も, 後から思えば 6 くらいから始め, 少し うつ変えてやってみたが，くる日もくる日も失敗ばかり であった，遂に卒業まであと 2 ケ月にせった或る日， 学生から「先生, 僕の卒論は大工仕事だけで終るのでし ょらか」と言われた時は本当に情ない思いであった。 そ れから数日たって引き上げた結晶 ( ? ) を顕微鏡で丹念に 調べていた学生が,「先生, 隅の方にストライプドメイ ンらしいものが $2 \sim 3$ 本見えます」と言った. 皆で見て 確かにこれはストライプドメインらしい, 磁石を近づけ て細人なれば問違いないといらわけで，磁石を近づけて みると確かに細くなったので, 皆で歓声をあげた次第で ある. 早速, 早稲田大学の小林教授に電話をして, 翌日 皆で乾盃をした，一度できるようになると，どうやって もできるもので，それから結晶成長のデータを随分とる ことができた. Blank の “Kinetics of Crystal Growth” の論文が出る前のことである.

もう暫く私事で恐縮であるが，自分で作れるようにな ると自分のアイディアを直ぐ試みてみるのに便利であ 
る. 早速に GGG - 磁性ガーネット膜 - GGG - 磁性ガー ネット膜の三層構造のものを作ることにした. 当初の目 的は一番上の層の記憶, 論理によって得られた結果を他 の位置に転送するのに，一度下の層に転写してそれから 直線的に転送して目的の位置で上の層に移そうというあ いまいなものであった．第 2 層目の非磁性層の GGG も LPE 法でつけてみようということになって, 磁性ガーネ ットの場合とほとんど変わらない $R_{1}, R_{2}, \cdots \cdots$ のパラメ ータで試みたところ成功して大いに得意がった. ただ し，上記のアイディアは未だできていない，後に日本電 気から発表されたデータはパラメータの值がわれわれの ものと大分異なっていた. 因みに, 現在, 私の研究室の 学生は日本電気のデータを使用しているようである.

もう 1 つ試みたのは磁性ガーネット膜の高保磁力化に よって光・熱磁気書込みを行なおうというのであった. これは研究室の伊藤助教授と井上助手が担当して $40 \mathrm{Oe}$ 以上のものも作れるようになった．磁気バブルを記憶に 使う場合にはでき得る限り低保磁力でなければならない ので各会社とも低保磁力の為に努力をされている時に, 私の研究室の仕事は世の中に背を向けたような研究であ った. 多分, この材料は会社の方にお願いしても一言で 断わられただろうと思っている。しかし，これは光・熱 磁気記録に役立った.

LPE で磁性ガーネット膜ができるようになった頃, 桜 井教授から GdCoの非晶質膜ができたとの連絡をいただ いた. 桜井教授の所もそれまで材料作りに大分苦労され たようであった，数日後，自動車のミラーほどもある非 晶質膜を見せられてびっくりしたり，LPE 膜ではこの大 きさのはとても無理だろらと思ったりした次第である.

IBM の Chaudhari が非晶質垂直磁化膜を発表したのと ほとんど同時であったように記憶している. LPE 膜も最 近 3 インチほどの GGG 基板が作れるようになったの で，先の非晶質膜とほとんど同じになったと考えてよい と思われる.ただ Chaudhari の文にもあったように, 空 ガラスにでもつけられるというのが GGG 研磨でさんざ ん苦労した人間にとっては羡しい限りである.

この磁性非晶質膜の話題は応用磁気の分野に新しい活 力を与えた. 超急冷磁性材料の研究も盛んになりつつあ り, 近い将来, 大型変圧器に応用されることも夢ではな いであろら. 最近, 通信用電源の国際学会の計画が九州 大学の原田耕介教授を中心に進められているのは真に当 を得た計画であろう。ご成功を祈る次第である.
最近の話題になっているものの 1 つに, 東北大学の岩 崎俊一教授の発明になる垂直磁化の記録があげられよ 5. 磁気ディスクの高密度記録が着実な進歩をしている 一方, 同じ分野でかかる新しい提案が出るところに応用 磁気の限りない将来を思わせる.

日本応用磁気学会の中に設けられた研究グループで名 古屋大学の内山普教授を中心とする磁気分離も最近の話 題であろらし, 超電導, 常電導をめぐって議論のある磁 気浮上も1963年当時には全く話題になっていなかったテ ーマである.

昨年の日本応用磁気学会学術講演会のセッション名を あげて見ても, 磁気記録, 磁気ヘッド, バブル材料, バ ブル物理, バブルデバイス, 液体急冷合金, 微粒子・イ ンバー, 薄膜, 非晶質材料, 磁気応用, 光・熱磁気記 録, 磁気光学, 磁気分離, と多岐にわたっているが高硅 素薄帯 5 件, 垂直形磁気記録 3 件などは1963年の Intermag. では全く見られなかったものであるし, 磁気光 学, 光・熱磁気記録の内容もすっかり変わっていて, 研 究テーマの限りない発展を思わせる. これらのセッショ ンを眺めると，かなり基礎的で理学系と見られるもの と，応用面で工学系と見られるものが仲よく同居してい る様子がよく伺え, 理学系, 工学系の協同の場としての 日本応用磁気学会の姿が示されていて誠に喜ばしい限り である。

先年，近角教授から “Magnetic”という言葉には“魅 力ある，親密な”という意味があることを初めて伺っ た. 急いで辞書を引いて見ると，なるほどそうである. 学会の会員の皆様が Magnetic な雾囲気の下にとどまる 所を知らない分野の発展にご協力くださることを期待し つつ筆をおくこととする.

\section{執筆者の紹介}

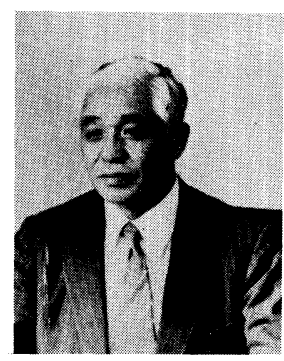

川西健次 かわにしけんじ 昭20東京大学第二工学部電気工学科 卒 現在日本大学理工学部電子工学 科教授 (工博) 専門磁性材料とそ の応用（特に磁気バブル, 光熱磁気 記録) 